\title{
Selected Reference Works, 2007
}

\author{
Sarah Witte and Mary Cargill
}

\begin{abstract}
This article follows the pattern set by the semiannual series initiated by the late Constance M. Winchell more than fifty years ago and continued first by Eugene Sheehy and then by Eileen Mcllvaine. Because the purpose of the list is to present a selection of recent scholarly and general works, it does not pretend to be either well balanced or comprehensive. A brief roundup of new editions of standard works is provided at the end of the articles. Code numbers (such as AC527) have been used to refer to titles in the Guide to Reference Books, 11th ed. (Chicago: ALA, 1996).
\end{abstract}

\section{Biography}

Dictionary of Medical Biography. Ed. W.F. Bynum and Helen Bynum. Westport, Conn.: Greenwood Press, 2007. 5 vols. $\$ 749.95$ (ISBN 0-313-32877-3; ISBN13 978-0-313-32881-7). LC 2006-022953.

By introducing this impressive five-volume set with six authoritative essays that cover Western, Islamic, Chinese, South Asian, Southeast Asian, and Japanese medical traditions and history, the editors offer both a historical perspective and a social context for the medical biographies that follow.

International in scope, the 1,140 medical biographies are written by a collection of 384 medical scholars from around the globe and range from ancient history to the present. They represent the social changes and major trends in medicine, from the entry of women into the field to the emergence of alternative therapies and the interaction of Western medicine with medical systems from other cultures.
Entries vary in length and conclude with bibliographies of both primary and secondary sources. One particularly helpful feature is the breakdown of longer entries into sections; for example, the four-page entry on Galen gives a nice overview, a biography, and then specific sections on each area of medicine from anatomy to classification of disease to his theory of the soul. Both Louis Pasteur and Sigmund Freud also receive extensive entries. Surprisingly, though, some medical luminaries receive short shrift-for instance, Jonas Salk, who as inventor of the polio vaccine had a significant impact on medicine and society.

The encyclopedia's editors, W.F. and Helen Bynum, have done a good job in making the information eminently accessible as well as aesthetically appealing. Each volume includes a list of all entries, and handsome black-and-white photographs and illustrations enhance and augment the text. The final volume

Sarah Witte and Mary Cargill are reference librarians in Butler Library at Columbia University; e-mail: spurgin@columbia.edu and cargill@columbia.edu. Although it appears under a byline, this list is a project of the reference departments of the Columbia University Libraries and notes are signed with the initials of one of the following staff members: Barbara Sykes-Austin, Avery Library; James L. Coen and Kathleen Dreyer, Business and Economics Library; Fadi H. Dagher, Lehman Social Sciences Library; Elizabeth Davis, Music Library; Alysse Jordan, Social Work Library; Anice Mills, and Junko Stuveras, Butler Library. 
ends with appendices that list individuals by country, by field of activity, and by birth/death dates. An index to both names and topics is an additional entry point. This notable reference work will be a valuable resource in any academic library and to scholars of medicine, history, and the social sciences. - A.M.

\section{Literature}

Encyclopedia of Italian Literary Studies. Ed. Gaetana Marrone. New York: Routledge, 2007. 2 vols. \$495 (ISBN 1-57958-390-3; ISBN13 978-1-57958390-3). LC 2006-048641.

The Encyclopedia claims to be "the first comprehensive reference work on Italian literature and culture to be published in English that offers a synoptic overview of the present state of the field though a wide array of critical perspectives." (Intro., xxxv) It is a collaborative work of 221 scholars from Italy, Europe, and Englishspeaking countries. The 591 articles aim to provide "critically substantial entries" on authors, works, and topics from Saint Francis of Assisi to Umberto Eco and Maria Corti. Typical entries range from 2 to 4 pages, although Dante occupies 18 pages.

Articles on authors have a standard format: general critical appraisal, short biographical information, bibliographies of selected works of the authors, and secondary works for "Further readings." Author entries are followed by essays on the author's major works. For example, the main article on Machiavelli is followed by articles on Discorsi sopra la prima deca di Tito Livio, il Principe, and La Mandragola. Each entry has its own bibliography listing first and critical editions in Italian, English translations, and selected secondary studies.

The encyclopedia has a broad definition of "Author" and includes cinematographers such as Fellini, Visconti, and De Sica. Its philosophy is inclusive: it covers not only canonical writers but also "those writers and subjects that traditionally have been neglected or overlooked by critics..." (Intro., xxv-xxxviii) It also includes an alphabetical list of entries, a thematic list of entries, and an index (separately numbered and conveniently in both volumes).

Recommended for both specialists and readers of Italian works in English translation.-J.S.

\section{Music}

Jasen, David A. Ragtime: An Encyclopedia, Discography, and Sheetography. New York: Routledge, 2007. \$125 (ISBN 0415-97862-9; ISBN13 978-0-415-978620). LC 2006-031343.

This work contains approximately 490 entries, alphabetically arranged, covering the musical form of ragtime, which the author defines as a "composition for the piano comprising three or four sections containing sixteen measures each that combines a syncopated melody accompanied by an even, steady duple rhythm" (think of the theme song from the movie The Sting, a ragtime piece "The Entertainer" by Scott Joplin).

The entries cover many different aspects of the topic. Some examples include concepts (such as Advanced Ragtime, 1913-1917), composers (Scott Joplin), performers (James Price Johnson), titles of songs with composer, date, and publication information ("Musician's Distress"), and publishers (Robbins Music Corporation). There is even an entry for the author, David Alan Jasen, a ragtime collector, producer, and author. The entries are liberally studded with black-and-white illustrations of varying quality.

Preceding the entries is a brief overview of ragtime provided by the author, as well as a thematic table of contents that groups the entries under eight large categories relating to chronology (such as Early or Folk Rags [1897-1905]), or topic (Joplin Tradition or Classical Ragtime).

Two appendices complete the work. One, titled "Rages on Record: A Discography," contains an alphabetical listing by title of all commercially released discs of ragtime on $78 \mathrm{~s}, 45 \mathrm{~s}$, and LPs 
released throughout the world since 1897. A "Ragtime Piano Rollography" provides a listing of piano rolls of ragtime manufactured and sold in the United States (Rollography is the generally accepted term for this type of discography, although Sheetography is used here on the title page). A third appendix contains an alphabetical listing by title of rags published in America, with composer, and publication information. An index of names and titles completes the work.

In summary, the work provides a great deal of information focused specifically on ragtime for piano from the perspective of a knowledgeable collector.-E.D.

Drone, Jeanette Marie. Musical AKAs: Assumed Names and Sobriquets of Composers, Songwriters, Librettists, Lyricists, Hymnists, and Writers on Music. Lanham, Md.: Scarecrow, 2007. \$100 (ISBN 0-8108-5739-1; ISBN13 978-08108-5739-1). LC 2006-000542.

At a time when the efficacy of name authority work is being questioned, this important volume appears which establishes authoritative name forms in the field of music. It provides an "index to over 15,500 assumed names and sobriquets of approximately 9,800 music composers, songwriters, lyricists, librettists, hymnists, and writers. The term assumed name includes legal name changes, pseudonyms, pen names, noms de plume, nicknames and initials."

Source volumes number around 400 comprehensive and biographical dictionaries, individual biographies, journals, Internet Web sites, as well as print and online copyright sources. Some focus on music styles (for example, Tin Pan Alley: The Composers, the Songs, the Performers and Their Time), some focus on international music (such as Österreich Lexikon), some relate to general reference (like Dictionary of Pseudonyms), some cite online sources (for instance, Song Index, www.chartwatch.co.uk/TopTen/songs/songndxA. $\mathrm{htm})$, among others. Every source listed contained assumed names and/or sobri- quets for three or more individuals. Print and online U.S. government copyright sources were also used, but only to verify names appearing in other sources (a forthcoming volume will list pseudonyms identified only in copyright sources).

The main section, titled "Original Names," follows the list of sources. It contains an alphabetical arrangement of each authentic individual name, with dates, occupation, an alphabetic listing of assumed names, and sources of the information. It is followed by the index of assumed names arranged alphabetically, word-by-word, with references to original names. In the final chapter, titled "Notes," original and assumed names are interfiled alphabetically, some with fuller explanatory information not included earlier (such as when a pseudonym is used by one individual alone, as well as a joint pseudonym with another).

A result of several decades of work, the author maintains that Musical AKAs is a "project with no end," a clearly evident assessment.-E.D.

\section{Dance}

George Balanchine Catalogue [electronic resource]. New York: George Balanchine Foundation, 2007. Free. www. balanchinedata.org/balanchine/search. jsp.

The free catalog is sponsored by the George Balanchine Foundation, supported by a gift from the Jerome Robbins Foundation; it is certainly not a case of getting what you paid for, since it is an exceptional resource. To some extent it is a revision and updating of the 1984 Choreography by George Balanchine: a Catalogue of Works, though its online features offer different and much more sophisticated search possibilities.

The catalog includes "complete premiere information about every known work staged or choreographed by George Balanchine" (press release), including the more than 400 ballets, in addition to musicals, plays, and television productions. The information, compiled by a group 
of noted dance scholars, is based on the opening night programs and other material and includes information about the cast, the music, the design, and often has useful supplemental information from other publications, unpublished material, interviews, and so forth. La Nuit, for instance, the first work in the chronology, now lost, quotes from the unpublished memoir of its star, as well as interviews of other dancers who saw it; this is so much more than a simple catalog.

The wealth of information can be searched by title (with cross references for variants), by dancer, and by other details, or browsed by date; the interface is very easy to use. In addition, there are separate lists of the festivals Balanchine directed, and a bibliography of his own writings, a list of books about him, or in which he is discussed (a bibliography of articles about him would obviously be too massive to include). There are additional bonuses, including a filmography and a videography compiled by the dance video expert Robert Greskovic and an annotated list of research collections compiled by Monica Moseley (formerly a librarian at the New York Public Library's Dance Collection) with links to many performing arts libraries throughout the world. Anyone interested in dance will welcome this outstanding resource.-M.C.

\section{Art and Architecture}

Castagno, John. Abstract Artists: Signatures and Monograms, An International Directory. Lanham, Md.: Scarecrow Press, 2007. 569p. \$225 (ISBN-13 9780-8108-5897-8). LC 2006-033604.

This is the latest addition to the author's nearly 20 years of published directories on artists' signatures and monograms, bringing together in this volume over 3,900 examples of identifying marks made by artists-painters, printmakers, sculptors, and photographers - "who have spent all or part of their careers in abstract art" (Intro., xi). Another 1,500 artists without known examples of their signatures are listed in a separate section, but their names have been included because their "exclusion would be counterproductive to the purpose of this book. This brings the total of listed artists to 3,800." (Ibid.)

As with the earlier titles (see below), the volume begins with a list of abbreviations of the sources used to identify artists' signatures, marks and monograms, that includes collection, auction, and exhibition catalogs, biographical dictionaries, catalogues raisonnés, illustrated magazines, reproduction indexes, encyclopedias, dictionaries and surveys, and library vertical files. The main section, here titled "Abstract Artists," is an alphabetical arrangement of six to eight artist entries per page, each separated into horizontal boxes with the artist's name, nationality, birth and death dates, and the source abbreviations printed to the left, leaving ample white space to the right to reproduce as many examples of signatures and monograms as have been found for each artist. Headers provide easy access to the first name at the top of each page. The next section is organized alphabetically by monograms and initials, again printed with the artist's name on the left, with the monograms reproduced on the right. Separate sections are organized by common surnames, alternative surnames, symbols and Oriental signatures, Cyrillic signatures, and illegible signatures of identifiable artists in any language. The 1,500 artists with no signatures comprise their own section, identified by name, nationality, dates and source abbreviations, concluding with an index of all of the artists' names.

Art collectors, dealers, scholars, and students will also welcome new editions, all published in the same format by Scarecrow Press in 2007, of three of Castagno's previous compilations of artists' signatures: Artists' Monograms and Indiscernible Signatures II: An International Directory From 1800 (1st ed. 1800-1991, c.1991); American Artists II: Signatures and Monograms from 1800, A Comprehensive Directory (1st ed. 1800-1989, c.1990); and European Artists II: Signatures and Mono- 
grams from 1800, A Comprehensive Directory (1st ed. 1800-1990, c.1990).-B.S.-A.

\section{The Architecture Reader: Essential Writ-} ings from Vitruvius to the Present. Ed. A. Krista Sykes. New York: George Braziller Publishers, 2007. 333p. il. \$35 (ISBN 978-0-8076-1579-9). LC 2006-034835.

It is more likely that this book will be off the open stacks and in circulation than it will be assigned to the reference shelf. But it is equally likely that it will be often recommended by librarians to students and nonarchitects in need of an introductory collection of writings on architecture. The editor has chosen forty documents, written primarily by architects from antiquity to the present day, and selected from them excerpts intended to "ponder, critique, and occasionally attack architectural norms and, in many cases, pose alternative methods of architectural thought and practice." (Preface, 11). These come in the form of journal articles, editorials, book chapters, lectures, interviews, and manifestos. (Ibid.)

The emphasis is on the architecture of the 20th and 21st centuries, with only the first seven documents dated before 1900. But those seven are essential to understanding what will follow, not only in terms of the built works of architecture but of architectural history writing and criticism in later centuries. They also help to distinguish on the first page of the table of contents the often confusing attributions of The Ten Books on Architecture (by Vitruvius Pollio, 1st century B.C.E., the only surviving ancient text on architecture, rediscovered in a monastery in the early 15th century); The Ten Books of Architecture by Leon Battista Alberti (also known as De re aedificatoria, published in 1485-and unconscionably misprinted here as 1846); Andrea Palladio's Four Books on Architecture (1570); and Claude Perrault, a translator of Vitruvius and himself author of Ordonnance for the Five Kinds of Columns after the Method of the Ancients (1683). The other three pre-modern authors are Abbot Suger, chronicling his rebuilding of the Church of St.-Denis in the 12th century in what was to become the Gothic style associated with medieval ecclesiastical architecture, E.-L. Boullée's 18th-century Architecture, Essay on Art, and E.-E. Viollet-le-Duc, the 19th-century restorer of the Gothic monuments of Paris and theoretician on the "structural rationalism" of Gothic architecture. The essay on "Style" was selected from his 10-volume Dictionnaire raisonné de l'architecture francaise du XIe au XVI sièle (1854-1869). All foreign language titles are presented here in English translation.

The remaining 20th- and 21st-century selections include the architectural lions of their times: Louis Sullivan, Frank Lloyd Wright, Le Corbusier, Walter Gropius, Henry Russell Hitchcock, Buckminster Fuller, Philip Johnson, Louis Kahn, Robert Venturi and Denise Scott Brown, Peter Eisenman, Charles Jencks, Bernard Tschumi, Rem Koolhaas, Daniel Libeskind, Norman Foster, Andres Duany, and Frank Gehry, as well as a few who would be largely unknown even to those with a prior exposure to architectural literature. There is a general introduction to acquaint the reader with the larger themes of architecture (When is a building just a building, and when is it architecture? What is an architect-a builder, a mason, a designer? A "man privileged with a classical education"?), and the roles the selected writers are seen to have played in the history of the subject. Each excerpt likewise is prefaced with background on the author/architect and the written work that follows. The modern English edition from which the excerpts are taken is cited, as are occasional footnotes to sources referred to in the texts. Finally, a section on suggestions for further reading, classified by dictionaries, surveys, anthologies and other readers, and for each of the forty authors, completes the volume.-B.S.-A.

\section{World History-Encyclopedias on Colonialism}

The encyclopedias on colonialism or 
colonies have a long history going back to the 19th century, the epoch of thriving colonial enterprises. In 1839-1851, A.J. van der Aa edited a twelve-volume encyclopedia of the Netherlands and her colonies. Editions of encyclopedias on the Dutch West Indies were published by Nijhoff in 1895-1921. German colonies are covered in: Schnee, Heinrich. Deutsches Kolonial-Lexikon. Leipzig, Quelle \& Meyer, 1920.

There are, however, surprisingly few good encyclopedias on the topic that meet the current scholarly standards. None covers successfully the entire human history and explores the nature, implication, and role of colonialism.

Many encyclopedias, whether on colonialism or another topic, have the annoying habit of rehashing the same well-worn pieces of information. Libraries might as well invest in a few reliable and well-written biographical dictionaries and up-todate general encyclopedias and dispose of the majority of specialized encyclopedias cluttering reference shelves.

Among the recent crops of encyclopedias on colonialism, the Encyclopedia of Western Colonialism since 1450 (2007) is a useful and well-edited work, although it is limited to modern Western European colonial enterprises.

\section{Encyclopedia of Western Colonialism} since 1450. Ed. Thomas Benjamin. Detroit: Macmillan Reference USA, 2007. 3 vols. il. maps. $\$ 395$ (ISBN 0028658434). LC 2006-010042. An electronic version is also available.

This work aims to offer, in over 400 articles in three volumes, "the most comprehensive, accessible, and international reference work about the entirety of Western colonialism from the Portuguese voyages of Prince Henry the Navigator in the fifteenth-century to the making of feature films about British colonialism in India in the twenty-first-century." (Pref., xiii) Its primary purpose is to provide "a teaching and learning resource for teachers and students."
Two tables in the preface ( $x v-x v i)$ neatly summarize the historical dimension of the colonial enterprises of mainly four countries: Great Britain, France, Belgium, and the Netherlands. The thematic outline (xxvii-xxx) is a useful tool to understand the scope and organization of this Encyclopedia. It serves also as a list of suggested topics for a student to explore. The list of contributors (xxxi-xl) not only gives names and institutional affiliations but also fields of specialization and the titles of articles contributed.

The articles are signed and include selected bibliographies of typically 5-10 titles and "see also" references. The encyclopedia offers a number of black and white photographs, etchings, drawings, maps, and chronological and statistical tables. Primary source documents in volume 3 (1161-1223) include 29 documents arranged by title. Each document is accompanied by a bibliography of the source publication and a brief introduction. There is a substantial index in volume 3. This Encyclopedia is also available as a full-text PDF file from Gale Virtual Reference Library. Recommended for college and university libraries.

\section{Encyclopedias on Colonialism by Country or Region \\ France}

Liauzu, Claude, et al. Dictionnaire de la Colonisation Française. Paris: Larousse, 2007. 646 p. il maps. 28 euros (ISBN 203-583343-4; ISBN 13 978-2-03-5833433). LC 2007-444663.

This dictionary of French colonialism can be used as a supplement to the more global and thematic approach of the Encyclopedia of Western Colonialism since 1450. This one-volume dictionary aims to be "une vulgarization de qualité" or a quality work for a general readership, as a synthesis of the achievements of scholarship up to now.

The articles are not signed, but the list of 62 contributors indicates the titles contributed by each person. There are no individual bibliographies for articles, but 
the book provides a general bibliography arranged by broad topic at the end of the volume (637-646). There are no crossreferences. The online index of names and topics that was supposed to be available on the Hermès site (www.hermes.jussieu. fr) was not found. Includes 16 pages of historical maps in color.

Suitable for university libraries and large public libraries serving Frenchspeaking readers.

Libraries would want to compare this to another recent French publication that I was unable to get hold of: Dictionnaire de la France coloniale. Ed. Jean-Pierre Rioux. Paris: Flammarion, 2007. 935p. il. (ISBN 9782081205581)

\section{Great Britain}

On the British Empire, there is a ten-yearold publication:

Stewart, John. The British Empire: An Encyclopedia of the Crown's Holdings, 1493 through 1995. Jefferson: McFarland, 1996. 370p. LC 96-005205.

This one-volume encyclopedia is arranged strictly by place name. Each entry consists of geographic description, start and end of colonial rule or the British Commonwealth affiliation, a brief history and a chronological list of British officials who ruled the area (chief commissioners, governors, lords proprietors, etc.).

Some possessions such as Channel Islands go back to 1066, but the majority of current and former British territories were acquired after 1600 . With detailed index (p. 285-370) and chronology (9-68). One advantage of this straightforward and simple arrangement by geographic name is that it shows the vast extent of the British Empire through the time span of 500 years. No bibliographies.

\section{North America}

The Encyclopedia of the North American Colonies (Ed. Jacob Ernest Cooke. New York: Scribner's, 1993. 3 vols. ISBN 0684192691. LC 93-007609) covers social, cultural, economic and political history of colonies in some depth. It discusses all areas of colonial life from economy to arts and has a good topical subject arrangement. Each article offers a substantial bibliography of both primary and secondary sources with brief annotation. With a detailed index (III, 793-865).

\section{International}

\section{Colonialism: An International, Social,} Cultural, and Political Encyclopedia. Ed. Melvin E. Page; Penny M. Sonnenburg, asst. ed. Santa Barbara: ABC-CLIO, 2003. 3 vols. il. LC 2003014643.

Since the 2007 encyclopedia limits itself to the "Western Colonialism," this older (2003) encyclopedia has not been entirely replaced. It covers colonialism internationally, also in three volumes, which are somewhat smaller in size. Articles are shorter, and there is no attempt at offering a survey or some narrative coherence to the entire work. If a library's main interest is in Western Europe, the new encyclopedia would be a better choice. If a library is aspiring to cover colonialism worldwide and has this set, it should be kept on the reference shelf as well.

The first two volumes are the encyclopedia proper; the third volume is a collection of historical documents grouped by "empire" ranging from the Ottoman and Austro-Hungarian Empires to the United States. Each document has a brief introduction and a source bibliography. This document section is more substantial than the document collection in the Routledge encyclopedia.

The alphabetically arranged encyclopedia volumes cover place and personal names, short surveys of various empires and topics such as "religion," "language," and a separate section for "Chronologies" for each of 15 empires. British, French and Spanish empires are divided into two parts: Western and Eastern Hemispheres. The remaining nine empires are Belgian, Dutch, German, Italian, Japanese, Ottoman, Portuguese, Russian, and United 
States. The chronologies cover the period from the Norman conquest (1066) to the Puerto Rican election in 2000.

The encyclopedia includes an article on the ancient Persian Empire, but there are no entries on the Roman Empire or the Holy Roman Empire. The emphasis is on early modern and modern history.

On the whole, there is no truly comprehensive encyclopedia of colonialism yet, so the best selections for an academic library would be the Western Colonialism since 1450 and regional subject coverage such as North American Colonies. And stay away from those spinoffs, which could easily be replaced by a good, general encyclopedia and standard biographical and geographical dictionaries.-J.S.

\section{American History}

Dubin, Michael J. Party Affiliations in the State Legislatures: A Year by Year Summary, 1796-2006. Jefferson, N.C.: McFarland, 2007. 213p. \$45 (ISBN 07864-2914-3 ISBN13 978-0-7864-29141). LC 2007-018479.

This would be my candidate for one of the best reference works of 2007 , and at $\$ 45$ it should be held by every library in the country supporting research in American or local history. It is slim, straightforward, and packed with useful information.

It is organized alphabetically by state, with each state chapter providing an overview of the state legislative history and subsections on statehood/constitutional origins; terms of the legislature; districts/ elections; membership/size; reapportionment/redistricting; election dates; and constitutions. These historical subsections are followed by tables organized by year. For example, in 1808, the New York Senate was composed of 23 members of the Democratic-Republican Party and 9 Federalists; while the Assembly was composed of 61 Democratic-Republicans, 48 Federalists, 3 Lewisites, and 1 Independent Republican. These tables are followed by notes and a section of Sources listing important resources, including histories, and newspapers and almanacs providing election coverage.

The volume also includes a summary of party affiliations by year, beginning in 1834, showing the number of state legislatures with a majority of Democrats or Republicans (or Whig). For instance, the table for 2002 shows that there were 15 Democrat-controlled legislatures, 22 Republican-controlled state legislatures, and 11 that were split. The table also gives a breakdown of state senates and state houses. Other useful sections include an annual chart showing the length of terms; a list of abbreviations; and a bibliography listing books and articles, almanacs, state manuals, Web sites, and newspapers.

Michael Dubin "began compiling these data over 35 years ago. Newspapers were the most important source in almost all the states, primarily prior to 1860." (Intro., 1). He is also the author of United States Gubernatorial Elections, 1776-1860 (2003), United States Presidential Elections, 1788-1860 (2002), and United States Congressional Elections, 1788-1997. With the current interest in local history, this is an invaluable resource for academic libraries of all sizes. - S.W.

\section{Business and Economics}

AdSpender [electronic resource]. New York: TNS Media Intelligence. Price varies. www.tns-mi.com/.

AdSpender contains advertising expenditures for millions of brands across eighteen types of media. AdSpender is the online version of the print source, $A d \$$ Summary. Both sources are published by TNS Media Intelligence (TNS MI), part of the TNS Group, which provides advertising data to advertising agencies and advertisers.

AdSpender allows users to create custom reports about the advertising expenses of brands and companies in different media; users can export results on an Excel spreadsheet. The data are available on a rolling five-year basis. TNS MI provides information about its 
methodology for collecting and reporting the data.

The AdSpender interface can be difficult to use at first. However, there is a helpful user manual available from the main search page. This database is a reliable resource for advertising expenditures and is recommended for large colleges and universities. - K.D.

Biech, Elaine. The Business of Consulting: The Basics and Beyond. 2nd ed. (Essential Resources for Training and HR Professionals). San Francisco: Pfeiffer, 2007. 302p. Includes CD-ROM. $\$ 50$ (ISBN 0-7879-9464-2, ISBN13 978-07879-9464-8). LC 2007-002780.

The author of this work is a thirty-year veteran of the training and consulting world working with business, government, and nonprofit sectors. Aspiring independent consultants are the target of this book, which aims to equip them with the tools necessary to decide on whether a consulting business will work for them, to figure out what to charge clients, to set up the practice including business model and marketing plan, and to establish all the ancillary processes such as record keeping and financial management.

The sequence of eleven chapters tracks from conception to the building of a new consulting practice in a comprehensive presentation that is too rich to describe in a brief review. Throughout, the content is highly pragmatic, with practical advice as well as tips and techniques based on real experience. Also included are around sixty e-ideas; these are "technology tips to assist the new consultant in laying a solid foundation, finding resources to build the business and identifying tools to save time and remain on the cutting edge of the profession."

The book comes with a CD-ROM containing a large number of professional consulting forms that are designed to be personalized. Highly recommended for libraries serving a business community.-J.C.

\section{Psychology}

Counseling and Psychotherapy Transcripts, Client Narratives, and Reference Works [electronic resource]. Alexandria, Va.: Alexander Street Press; Sage Publications. Price varies. http://asp6new.alexanderstreet.com/ psyc/psyc.index.map.aspx.

The new database, Counseling and Psychotherapy Transcripts, Client Narratives, and Reference Works (formerly Primary Sources in Counseling and Psychology) from Alexander Street Press promises a depth and breadth of invaluable material to social workers, clinical psychologists, and historians alike. This groundbreaking digital collection is the first of its kind to combine resources that support theoretical and evidence-based approaches while also validating practice wisdom, offering previously unavailable access to transcripts of psychotherapy sessions as well as full text of selected reference sources and handbooks.

The postrelease name change was a savvy marketing decision, considering that a large part of its target audience are nonhistorians who wouldn't necessarily have related to the primary source label. The new title offers a more succinct description of the contents of the resource, and it is a rare mental health practitioner who would not be enthusiastic about the ability to search across psychotherapy transcripts and client narratives, not only to understand whence the mental health professions came, but in fact, to explore answers to complex contemporary psychoanalytic issues as well. - A.J.

\section{Sociology}

Encyclopedia of Measurement and Statistics. Ed. Neil J. Salkind. Thousand Oaks, Calif.: Sage Publications, 2007. 3 vols. \$395 (ISBN 1-4129-1611-9). LC 2006-011888.

Organized in the usual A-Z format in three volumes, Sage's Encyclopedia of Measurement and Statistics consists of over 500 signed and cross-referenced entries. It includes a list of entries and an index 
in each volume; a glossary of concepts, an annotated list of Internet sites about statistics, and a guide recommending basic data collection process at the end of volume three; and a broad bibliography. To further facilitate the finding of information, the Encyclopedia includes a Reader's Guide in which entries and related concepts are listed by theme, such as "Computer Topics and Tools," "Descriptive Statistics," "Evaluation," "Probability," "Tests by Name," etc.

The Encyclopedia generally succeeds in offering a broad overview of the major but wide and diverse concepts in the fields of measurement and statistics. It also includes 19 biographical entries of relevant figures in the two fields. Few of the entries seem to delve deeper than the stated objective. But the writing is generally accessible.

The editor, Neil J. Salkind, is a professor of Psychology and Research in Education at the University of Kansas in Lawrence. He is immersed in the field and is the author of numerous publications, including most recently Statistics for People Who (Think They) Hate Statistics: the Excel Edition (2007), Encyclopedia of Human Development (2006), and Theories of Human Development (2004). From 1988 to 2001 he served as the editor of Child Development Abstracts and Bibliography.

The Encyclopedia is not a replacement for K. Kempf-Leonard's Encyclopedia of Social Measurement (2005). It is rather highly recommended for undergraduate libraries. But some graduate students in professional schools, such as education, social work, and criminology, might also find this resource very useful.-F.H.D.

\section{Children and Television: Fifty Years of}

Research. Ed. Norma Pecora, John P. Murrray, and Ellen Ann Wartella. Mahwah, N.J.: Lawrence Erlbaum, 2007. Includes a CD-ROM. $\$ 79.95$ (ISBN 0-8058-4138-5). LC 2005-044942.

This bibliography is a useful collection of eight scholarly and comprehensive review articles: "The changing nature of children's television: fifty years of research" by Norma Pecora; "From attention to comprehension: how children watch and learn from television" by Aletha C. Huston, David S. Bickham, June H. Lee, and John C. Wright; "The impact of television on cognitive development and educational achievement" by Marie Evans Schmidt and Daniel R. Anderson; "Television, social rules, and marginality: portrayals of the past and images for the future" by Gordon L. Berry; "Is television healthy?: the medical perspective" by Michael Rich; "Advertising and consumer development" by Nancy A. Jennings and Ellen A. Wartella; "TV violence: research and controversy" by John P. Murray; and "Health, drugs, and values" by Elizabeth P. Lorch. The essays include bibliographies, and there is an extensive bibliography (233-61) arranged by author, at the end of the book. Subject and author indexes provide additional subject access to the essays. Children and Television should be especially useful for students looking for scientific studies. One disappointment is that the bibliography on the CD is simply a PDF of the alphabetically arranged bibliography contained in the book. I suppose it might be possible to do some crude searches to identify publications by year, but it would have been so much better to include a searchable database, where one could sort the titles by date, journal, or keyword.-S.W.

\section{Law and Public Policy}

HeinOnline [electronic resource]. Buffalo: William S. Hein \& Company. Price varies. http://www.heinonline.org/

HeinOnline is a database available from the long-established distributor of legal periodicals William S. Hein \& Co. In collaboration with Cornell University Information Technologies, Hein set out in 2002 to digitize legal and related periodicals. The database currently includes 22 library collections such as the Law Journal Library, the Treaties and Agreements Library, the U.S. Supreme Court Library, the U.S. Attorney General Opinions, and 
the Legal Classics. However, the database is not only about law-related material. Among the library collections are the Federal Register Library, the U.S. Presidential Library, the Code of Federal Regulations, and the Federal Legislative Histories Collection. Coverage includes charts, graphs, illustrations, and photographs from the original publications.

The database search functionality has improved over previous iterations. There are help features including a user's guide and various tutorials on the homepage. On every page there is a menu feature such as title lookup, citation navigator, and search, which help researchers to find publications. Words or phrases can be used in searches within a library collection. Searches can be limited by date, by journal, and/or by primary (article, comments, reviews, etc.) or secondary (contents, editorials, misc.) types. Results can be viewed in PDF from which they can then be printed or downloaded. There is also an option to link documents to a permanent URL. But there is no option to search across library collections.

Subscribers to HeinOnline include law schools, law firms, corporations, courts, and other institutions in 150 countries. The annual subscription fee is based on University FTE. Simultaneous multiuser access is available by IP address authentication. The database is highly recommended for law school libraries and libraries serving departments of Political Science and History as well as schools of International Affairs, Public Policy, Criminal Justice, or Social Work. -F.H.D.

\section{New Editions, Supplements, etc.}

The second edition of the monumental Encyclopedia of the Social Sciences (Detroit: Macmillan, 2008. 9 vols. \$972; 1st ed. 1968-91. Guide CA36) has appeared. It has revised the contents and added almost 3,000 new entries. The New Encyclopedia of Africa (Detroit: Thomson/Gale, 2008. 5 vols. \$575) is an expansion of the 1997 Encyclopedia of Africa South of the Sahara. The new edition now covers the history and current events of the entire continent. Facts on File has published a second, revised edition of the Encyclopedia of Terrorism (New York: Facts on File, 2007. \$95; 1st ed., 2002), which "seeks to update information about groups...It also includes information about new agencies and policies generated by the events of 9/11." (Intro.)

The tenth edition of the McGraw-Hill Encyclopedia of Science and Technology (New York: McGraw-Hill, 2007. 20 vols. \$2995; 1st ed. 1960. Guide EA81) has more than 1,700 new and updated entries. The online version will provide selected updates.

There have been several new editions of history reference works. David R. Woodward has revised his America and World War I: A Selected Annotated Bibliography of English-language Sources (New York: Routledge, 2007. \$95; 1st ed. Garland, 1985). It now reflects "the current broader interpretation of military history because it examines the war's impact on society, institutions, and thought" (Pref.). The Encyclopedia of the Great Plains Indians (Lincoln: Univ. of Nebraska Pr., 2007. \$24.95) is in fact an excerpt, with some twenty new entries and many new photographs, of the Encyclopedia of the Great Plains (Lincoln: Univ. of Nebraska Pr., 2004). New Makers of Modern Culture (London: Routledge, 2007. 2 vols. \$395) is an updated revision of The Makers of Modern Culture (Routledge, 1981) and Makers of Nineteenth-century Culture (Routledge, 1982). Wilson Scott has compiled the second edition of Resting Places: the Burial Sites of Over 10,000 Famous Persons (Jefferson, N.C.: McFarland, 2007. \$75; 1st ed. 2001) which adds 3,000 people to the original 7,000. It covers deaths (including many non-Americans) through December 3, 2005, and has brief biographies, with often difficult to find information about the funerals. An index includes place names.

British Electoral Facts, 1832-2006 (Aldershot, Hants.: Ashgate, 2007. \$154.95) is now in its seventh edition and supersedes British Electoral Facts, 1832-1996, 
published in 2000 (Guide CJ364). Martin Gilbert has also issued the seventh edition of The Routledge Atlas of Jewish History (London: Routledge, 2006. \$100; $1^{\text {st }}$ ed. entitled The Jewish History Atlas. New York: Macmillan, 1969. Guide DA52). The new edition updates the maps and includes information illustrating the rise in anti-Semitic incidents. The second edition of The Atlas of the World's Religions has been published (New York: Oxford Univ. Pr., 2007. \$110; 1st ed. 1999) with updated entries, more current suggested readings, and eight new subjects, including Mormons, religion and the environment, and Christianity in South America.

The Encyclopaedia of Islam Three is the third edition (Leiden: Brill, 2007-; 1st ed. 1911-38. Guide BC503) of the indispensable source. The publishers plan to issue four volumes a year, and it will include more detailed coverage of Islam in the twentieth century.
Supplements and additional volumes include a cumulative index to the eleven volumes of Congressional Quarterly's Congress and the Nation, so there is now an index to "legislation, issues, and events" from the Roosevelt/Truman administration to the first George Bush administration. The New Encyclopedia of Southern Culture has issued four new volumes: vol. 5 Language, vol. 6 Ethnicity, vol. 7 Foodways, and vol. 8 Environment. Glyn Burgess has issued the third supplement to Marie de France: An Analytical Bibliography, now published by Tamesis, in Suffolk, England, which "lists and describes all editions, translations, and studies relating to the three works commonly attributed to Marie de France" published from 1995 to 2006. The Joint Committee on Printing announced in 2007 that the December 2004 issue of the Monthly Catalog of Untied States Government Publications (Guide AF111) will be the last paper issue, and that only the online version will be available. -M.C.

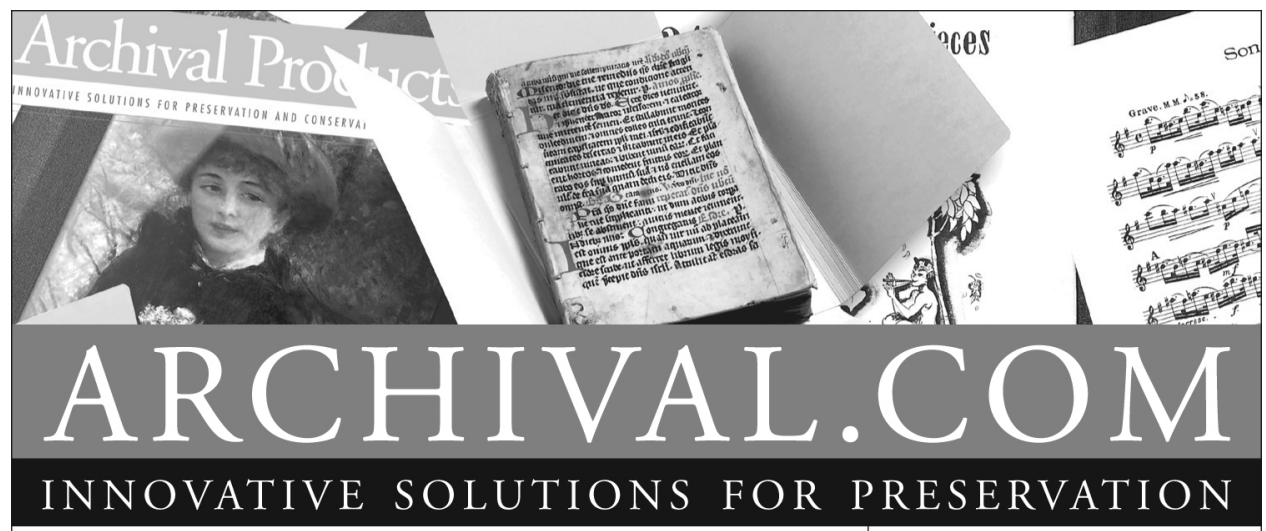

Call for a complete catalog

Pamphlet Binders Music Binders Archival Folders Manuscript Folders Hinge Board Covers Academy Folders Newspaper/Map Folders Bound Four Flap Enclosures Archival Binders
Polypropylene Sheet \& Photo Protectors Archival Boards Adhesives

Bookkeeper Century Boxes

Conservation Cloths Non-Glare Polyproplyene Book Covers

CoLibri Book Cover System

\section{ARCHIVAL PRODUCTS}

P.O. Box 1413

Des Moines, Iowa 50306-1413

Phone: 800.526.5640

Fax: 888.220.2397

E-mail: custserv@archival.com Web: archival.com 


\section{NEW ACRL PUBLICATIONS}

Library 2.0 Initiatives in Academic Libraries

Laura B. Cohen, editor

Library 2.0 Initiatives in Academic Libraries presents twelve unique case studies describing the application of Web 2.0 tools and techniques. Additionally, it covers the integration of library resources into Blackboard-delivered curricula, the use of emerging technologies, and the incorporation of catalog and other library resources into Web sites.

\$35.00; 179p., 978-0-8389-8452-9
Information Literacy Programs in the Digital Age

Alice Daugherty and Michael F. Russo, compilers

Information Literacy Programs in the Digital Age is a showcase of twenty four unique online information literacy projects from community colleges, research universities, and liberal arts colleges. Authors discuss the development of online information literacy courses and tutorials, along with best practices for embedding information literacy instruction in to discipline courses and programs.

\$48.00; 278p., 978-0-8389-8444-4

Studying Students: The Undergraduate Research Project at the University of Rochester Nancy Fried Foster and Susan Gibbons, editors

The book provides a view into the groundbreaking application of ethnographic tools and techniques to the understanding of undergraduate students and their use of information. The publication describes findings of the work at the University of Rochester River Campus Libraries and provides insight into how academic librarians might use these techniques on their own campuses. $\$ 28.00 ; 100$ p., 0-8389-8388-X

Three-volume Set; $\$ 440.00$

\section{COMING SOON!}

Practical Pedagogy for Library Instructors: 17 Innovative Strategies to Improve Student Learning

Douglas Cook and Ryan Sittler, editors

\section{Visit our online publications catalog for more information! www.ala.org/publications}

